\title{
Larvae of the deep-sea Nematocarcinidae (Crustacea: Decapoda: Caridea) from the Southern Ocean
}

\begin{abstract}
The early larval stages of the deep-sea Nematocarcinidae, Nematocarcinus longirostris Bate, 1888, from the south-western Atlantic Ocean, and $N$. lanceopes Bate, 1888, from the high Antarctic Weddell Sea, were obtained from plankton catches, described and illustrated. Furthermore, field collected larvae of $N$. lanceopes were compared with larvae hatched and reared under constant laboratory conditions. The morphology of larvae in both species clearly indicates a planktotrophic and extended mode of larval development. This is an outstanding feature in deep-sea and especially in high-latitudinal caridean shrimp species, and the consequence of such reproductive trait for life history adaptations to both deep-sea and polar environments is discussed.
\end{abstract}

\section{Introduction}

The deep sea is the largest aquatic environment on earth, but still belongs to the least studied areas. It is principally characterised by low temperatures, high pressure, and low food availability for organisms living there (Thiel et al. 1996). Except for the effect of pressure, very similar conditions are found in polar seas, in particular in the Antarctic realm (Clarke 1987). Consequently, adaptation to both low food availability and low temperatures is not exceptional,

This revised version was published online in November 2004 with corrections to the figure part lettering.

S. Thatje $(\bowtie) \cdot$ W. E. Arntz

Alfred Wegener Institute for Polar and Marine Research,

PO Box 120 161, 27515 Bremerhaven, Germany

E-mail: sthatje@awi-bremerhaven.de

R. Bacardit

Juana Azurduy 1611, 1429 Buenos Aires, Argentina but rather the rule in the marine realm, and thus should have forced a great variety of evolutionary responses to the life history challenges under such environmental conditions.

Very little is known about the early life history of deep-sea decapods (Anger 2001). Life history studies under similar conditions in the Antarctic, however, revealed strong adaptation in both adults and larval decapods to low temperatures and limited food availability (Arntz et al. 1992; Gorny et al. 1992; Clarke 1993a, b; Thatje et al. 2003). Among other adaptations (see Thatje 2004), larval developments in caridean shrimp at high latitudes are characterised by large and advanced larvae at hatching, abbreviated larval development and reduced variability in the number of developmental pathways (variability in the number of larval stages), and a high resistance to starvation, at least in the first zoeal stage (Wehrtmann 1991; Thatje et al. 2003; Thatje et al. 2004a, b). Some lithodid crab species even evolved completely food independent lecithotrophic larval development in the cold, which enabled them to uncouple from the mismatch of prolonged developmental times at low temperatures and short periods of primary production and, consequently, food availability (Clarke 1982, 1987, 1993b; Anger et al. 2003, 2004; Calcagno et al. 2003). Such complete reduction of pelagic life stages is, however, almost unknown in marine shrimp (for discussion see Thatje et al. 2003, 2004a).

The Nematocarcinidae are a typical deep-sea caridean family with a wide bathyal distribution (Wenner 1979; Iwasaki and Nemoto 1987; Retamal 1981; Boschi et al. 1992; Cartes 1993; Spivak 1997; Burukovsky 2001). Nematocarcinus longirostris is known to occur in South Chilean waters, the Southern Atlantic, and circumAntarctic eastwards to Marion and Crozet Islands. It has been recorded off Japan and South Africa and in Eastern Antarctica, including the Indian Ocean sector of the Southern Ocean and parts of the Ross Sea (Kirkwood 1984; Gorny 1999). N. longirostris has been described either as a bathypelagic or bathybenthic 
species and shows a bathymetric distribution from about 500 to 3,531 m (Yaldwyn 1965; Zarenkov 1968; Kirkwood 1984). Zarenkov (1968) was the first to suggest that $N$. longirostris is a synonym for $N$. proximatus (e.g. Boschi et al. 1992), thus greatly expanding its geographic range as to the depth and distribution.

Nematocarcinus lanceopes is endemic to Antarctic waters of the Weddell and Scotia Seas (south of $55^{\circ} 30 \mathrm{~S}$ ) (Retamal 1981; Arntz and Gorny 1991; Boschi et al. 1992; Gorny 1999). It is distributed from about $840 \mathrm{~m}$ water depth off the high Antarctic shelf to abyssal depths of at least 4,000 m (Gutt et al. 1991; Arntz et al. 1999; Gorny 1999; Romero et al. 2003). Occasionally, $N$. lanceopes was also found on the continental slope south off Tierra del Fuego, at the southernmost tip of South America (Arntz et al. 1999). Both $N$. lanceopes and $N$. longirostris show overlapping areas of distribution in waters off South Georgia and the Sandwich Islands in the Scotia Sea, as has been confirmed recently (Boschi et al. 1992; Spivak 1997; Romero et al. 2003).

In the present work we describe and illustrate the first two zoeal stages of $N$. lanceopes and $N$. longirostris as well as one advanced zoeal stage in the latter. So far there are only a few, but not very detailed, data of larvae of this genus available (Williamson 1962). Our laboratory rearing of larvae of $N$. lanceopes from the high Antarctic Weddell Sea is one of very few successful attempts in deep-sea shrimp. The larval developmental cycle is discussed in relation to the conditions characterising cold deep-sea and high-latitude environments.

\section{Materials and methods}

The larval material of $N$. longirostris was collected during the cruises of the vessels "Walther Herwig" and "Shinkai Maru" carried out on the Argentine shelf and the continental slope in the south-western Atlantic Ocean (Fig. 1A, C) in 1978 and 1979, respectively. Samples were collected vertically from the seafloor to the surface or $100 \mathrm{~m}$ to the surface by means of a Bongo net of $330 \mu \mathrm{m}$ mesh size, and were preserved in $3 \%$ formalin solution buffered with hexamethylenetetramine. Complete descriptions of the cruises and additional information on oceanographic measurements can be obtained from Ciechomski et al. (1979) and Cousseau et al. (1979).

Larval material of $N$. lanceopes (zoeal stages I + II) was obtained from vertical multinet hauls $(100 \mu \mathrm{m}$ mesh size) in the high Antarctic Weddell Sea during the RV "Polarstern" campaign ANT XXI/2 in November/ December 2003 (Fig. 1B, C). The plankton material obtained during this cruise has been compared with larvae reared on board RV "Polarstern" (zoeal stages I + II) during the same cruise.

Ovigerous females were caught using an Agassiz trawl (AGT) at about 1,488-1534 $\mathrm{m}$ water depth (PS65/109-1 7047.88'S; $\left.11^{\circ} 21.56^{\prime} \mathrm{W}\right)$. Since all egg carrying females obtained from that haul did not appear sufficiently healthy to survive the rearing stress, we decided to dissect the egg batches from the female pleopods and incubated the batch of one female, which
Fig. 1 Sampling locations of larvae of Nematocarcinus in the Southern Ocean. A Overview of study areas, $\mathbf{B} N$. lanceopes in the Weddell Sea (Antarctica), C $N$. longirostris in the southwestern Atlantic Ocean; zoeal stages I+ II of $N$. longirostris and $N$. lanceopes were caught in October 1978 and November/ December 2003, respectively. The advanced larva of $N$. longirostris was caught in May 1979 (C).

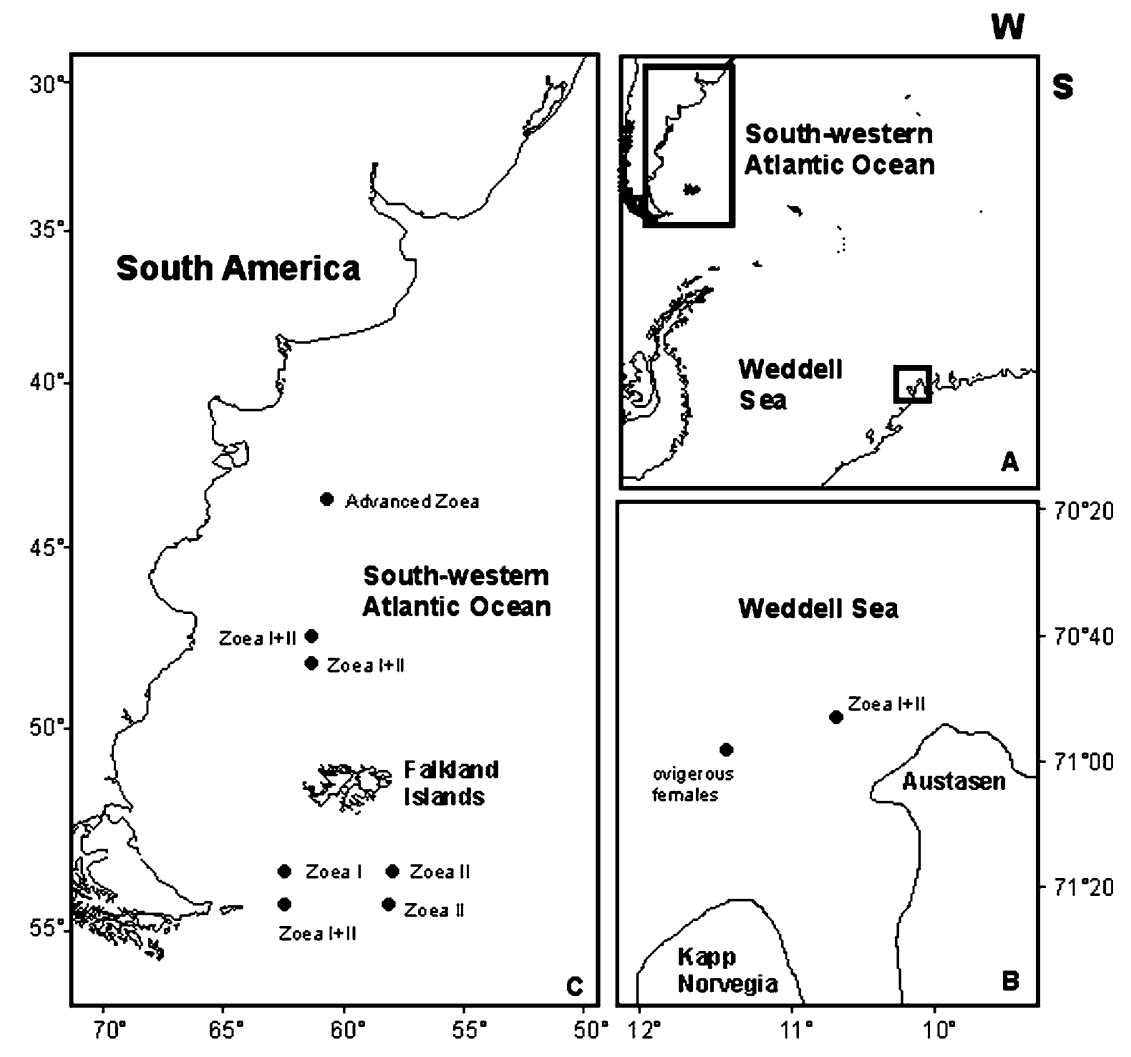


already showed hatched larvae trapped between the pleopods. The batch was kept in an aerated beaker of 1.51 water content and maintained at $0^{\circ} \mathrm{C}\left(\mathrm{SD} \pm 1{ }^{\circ} \mathrm{C}\right.$; salinity about 34 ) and the larvae hatched independently during the first night of incubation. On the following morning, larvae were then selected with a long glass pipette from the bottom of the beaker since larvae showed rather low capability of swimming actively. Only actively moving larvae were considered for the study of larval development and morphology. The larvae hatched during several days. Several cohorts from subsequent hatching days were maintained in individual culture (one larva per $100 \mathrm{ml}$ cup). Water was changed every day and food in the form of ice algae (the algae cocktail was obtained from plankton hauls) was given every second day. Larvae of $N$. lanceopes reached the zoea II instar after $21 \pm 3$ days $(n=12)$ in development. Rearing of larvae of $N$. lanceopes on board RV "Polarstern" needed to be finished at the end of cruise ANT XXI/2, which unfortunately did not allow for completing the larval development study.

Carapace (CL) and total lengths (TL) of the larvae were measured from the base of the rostrum between the eyes to the posterior dorsal margin of the carapace, and to the posterior margin of the telson, respectively. The terminology used for the differentiation of the larval phases, larval morphology and the worked out characteristics between species and larval stages corresponds to that suggested by Gurney (1942), Williamson (1962, 1982), and Haynes (1981, 1985).

\section{Description of zoeal stages}

Order Decapoda Latreille, 1802

Suborder Pleocyemata Burkenroad, 1963

Family Nematocarcinidae Smith, 1884

Remark The first zoeal stages are described and illustrated in detail, and only the changes are described and illustrated in subsequent stages.

Nematocarcinus longirostris Bate, 1888

Zoea I (Fig. 2A-K)

$\mathrm{CL}=1.9 \mathrm{~mm} \mathrm{SD} \pm 0.05 ; \mathrm{TL}=7.3 \mathrm{~mm} \mathrm{SD} \pm 0.05 ; N=8$

Carapace (Fig. 2A, B) Eyes sessile, rostral spine present, without denticles; pterygostomic spines present; posterior margin of carapace rounded; 1 dorsal anterior protuberance.

Antennule (Fig. 2C) Uniramous, peduncle unsegmented, with 1 distal seta in inner side; outer flagellum unsegemented, bearing 4 aesthetascs and 1 seta.
Antenna (Fig. 2D) Biramous, protopod unsegmented with 1 well-developed spine at inner distal part; exopod 6-segmented, with $1 / 1,0 / 1,1 / 10 / 1,1 / 1,4$ plumodenticulate setae; 1 strong ventral spine at basis.

Mandible (Fig. 2E) Incisor process with strong teeth; molar process with abundant small teeth; without palp.

Maxillule (Fig. 2F) Coxal endite with 7 setae; basial endite with 2 strong and 3 thinner plumodenticulate cuspidate setae; palp 2-segmented with 2, 3 setae; outer lobe represented by 1 small protuberance and 3 plumose setae.

Maxilla (Fig. 2G) Proximal coxal endite with 11 setae; distal endite with 4 setae; basial endites with 4 setae each; palp incompletely 4-segmented, with 3, 2, 1, 2, 2 setae; scaphognathite with 1 terminal flagellum.

Maxilliped 1 (Fig. 2H) Coxa with 6 setae; basis with 4 groups of 3 setae each; exopod with 1 subterminal and 3 terminal setae; endopod 4-segmented with 2, 1, 2 and $1+3$ setae.

Maxilliped 2 (Fig. 2I) Coxa with 2 setae; basis with 4 groups of 1,2, 3, and 3 setae, from proximal to distal segment; exopod with 2 subterminal and 3 terminal setae; endopod 4-segmented with 3,1,2, and 5 setae.

Maxilliped 3 (Fig. 2J) Basis with 4 setae; exopod with 2 subterminal and 3 terminal setae; endopod 4-segmented with $2,1,2$, and $1+3$ setae.

Pereiopods (Fig. 2A) Absent.

Pleon (Fig. 2A) Somites 1-3 partly fused; somite 3 with 1 conspicuous dorsal prominence; somites 4-5 with latero-ventral margins rounded; margins of all somites smooth; somite 6 fused with telson; pleopods absent.

Telson (Fig. 2K) Convex, spatulous, without medial indentation; posterior margin with $7+7$ plumose setae; pairs of different length, only pairs 2 and 5 of similar length.

Nematocarcinus longirostris Bate, 1888

Zoea II (Fig. 3A-F)

$\mathrm{CL}=2.4 \mathrm{~mm} \mathrm{SD} \pm 0.05 ; \mathrm{TL}=9.1 \mathrm{~mm} \mathrm{SD} \pm 0.05 ; N=5$

Carapace (Fig. 3A, B) Eyes pedunculated; carapace similar to previous stage; with 2 dorsal protuberances.

Antennule (Fig. 3C) Peduncle 3-segmented; first segment with 6 setae above distal outer margin and 1 large seta above inner margin; segments 2 and 3 with 5 and 2 setae above distal outer margin; outer flagellum 


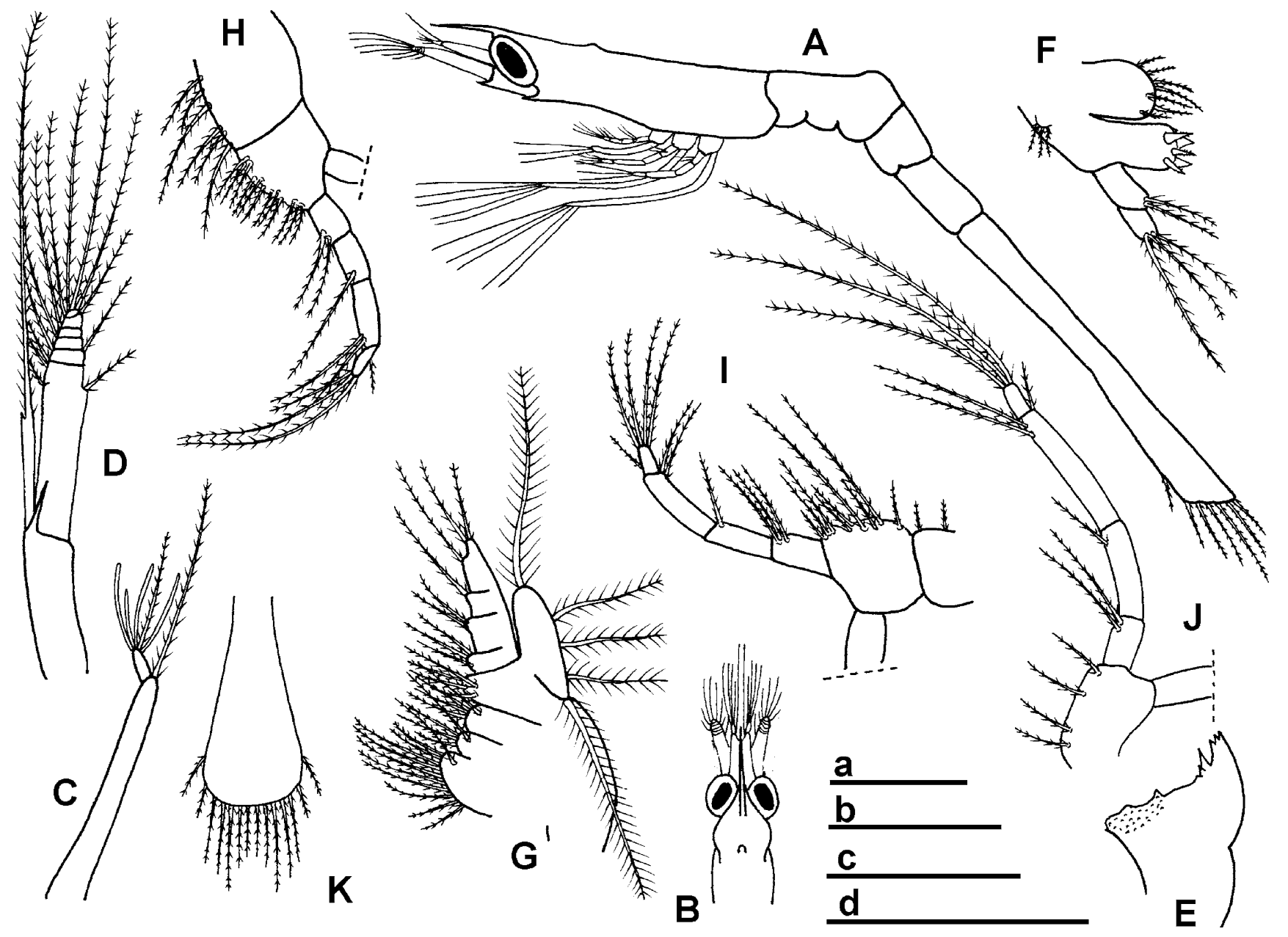

Fig. 2 Nematocarcinus longirostris Bate, 1888. Zoea I; A general aspect, lateral view, B cephalothorax, dorsal view, $\mathbf{C}$ antennule, D antenna, $\mathbf{E}$ mandible, $\mathbf{F}$ maxillule, $\mathbf{G}$ maxilla, $\mathbf{H}$ maxilliped 1, I maxilliped 2, J maxilliped 3, $\mathbf{K}$ telson, dorsal view. Scale bars $\mathbf{a}=1 \mathrm{~mm} \quad(\mathbf{A}, \mathbf{B}, \mathbf{K}), \quad \mathbf{b}=0.2 \mathrm{~mm} \quad(\mathbf{E}-\mathbf{G}), \mathbf{c}=0.5 \mathrm{~mm} \quad(\mathbf{C}, \mathbf{D}) ;$ $\mathbf{d}=0.5 \mathrm{~mm}(\mathbf{H}-\mathbf{J})$.

unsegmented, with 4 apical aesthetascs; inner flagellum represented by 1 large plumose seta, broadened at base.

Antenna (Fig. 3D) Biramous, protopod unsegmented with 1 well-developed spine at inner distal part; exopod 5 -segmented, with $2 / 2,0 / 1,0 / 10 / 1,5$ plumodenticulate setae; 1 strong ventral spine at basis.

\section{Mandible Without changes.}

Maxillule Coxal endite with 8 setae; basial endite with 3 strong and 4 thinner plumose spines.

Maxilla (Fig. 3E) Coxal endite proximally with 13-14 setae.

Maxilliped 1 Basis with 4 groups of 3, 3, 5, and 3 setae from proximal to distal part; endopod with $3,1,2$, and 4 setae, respectively.
Maxilliped 2 Exopod with 2 apical setae and 4 pairs of subterminal setae; endopod with incomplete segmentation between carpus and propodus, ischium with 4 internal setae.

Maxilliped 3 Exopod with 2 apical setae and 6 pairs of subterminal setae; endopod of 5 segments, carpus with 1 outer and without inner seta.

Pereiopods First pair of pereiopods represented by small buds.

Pleon Without changes.

Telson (Fig. 3F) Convex, with $8+8$ plumose setae, central pair of minor size; pairs 2 and 3 of similar length; the other pairs of different length; with $3+3$ short lateral plumose setae.

Nematocarcinus longirostris Bate, 1888

Zoea, advanced stage (Fig. 4A-I)

$\mathrm{CL}=5.4 \mathrm{~mm} ; \mathrm{TL}=21.9 \mathrm{~mm} ; N=1$ 


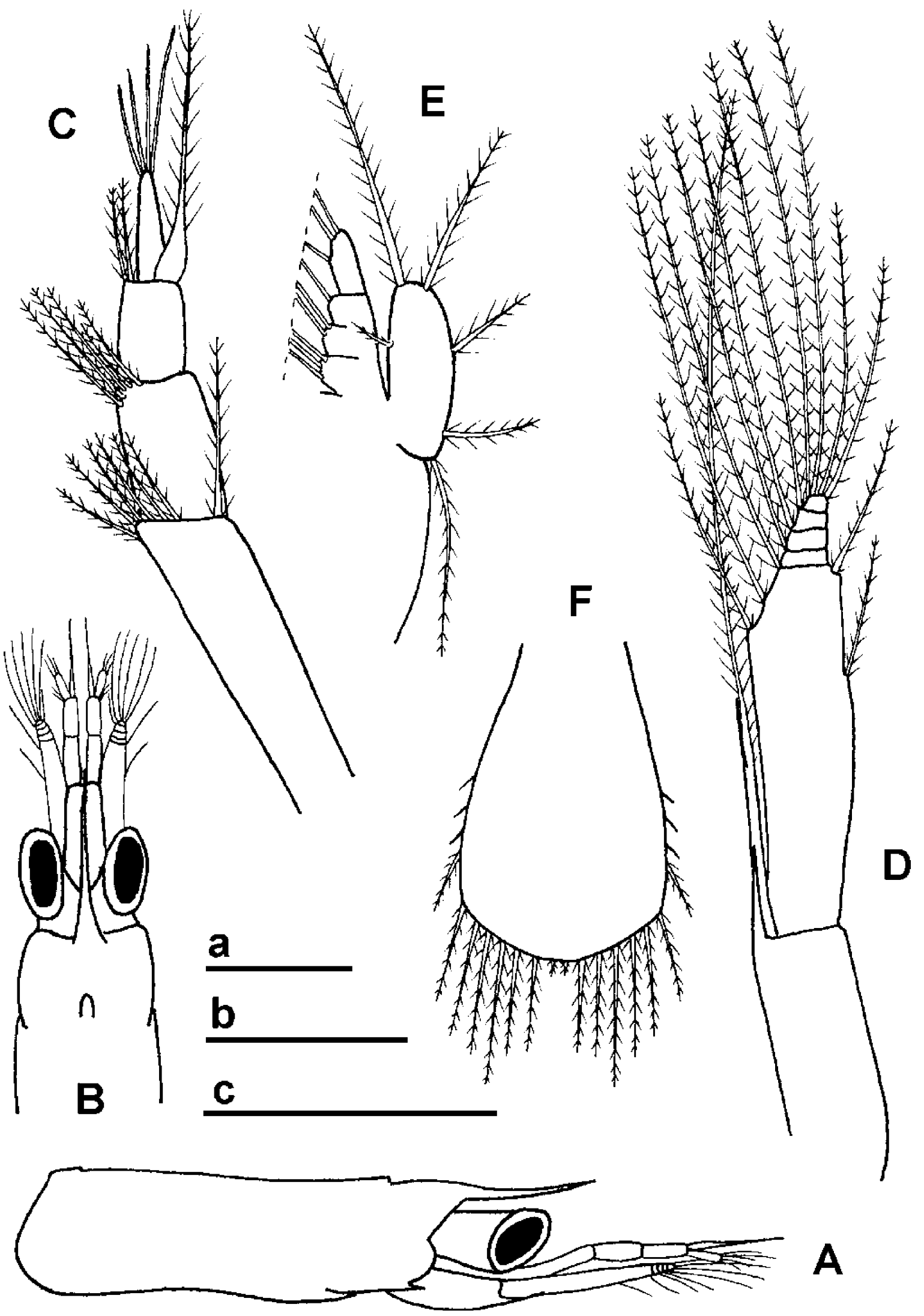


Fig. 3 Nematocarcinus longirostris Bate, 1888. Zoea II; A cephalothorax, lateral view, B cephalothorax, dorsal view, C antennule, D antenna, E maxilla, $\mathbf{F}$ telson, dorsal view. Scale bars $\mathbf{a}=0.2 \mathrm{~mm}(\mathbf{E})$, $\mathbf{b}=1 \mathrm{~mm}(\mathbf{A}, \mathbf{B}, \mathbf{F}), \mathbf{c}=0.5 \mathrm{~mm}(\mathbf{C}, \mathbf{D})$.

Carapace (Fig. 4A) Rostrum straight, with 12 dorsal and 2 ventral spines; antennal and pterygostomic spines present; 1 dorsal anterior protuberance.

Antennule (Fig. 4B) Peduncle 3-segmented; first segment with 2 strong medial spines and 6 setae above inner margin, outer margin with various distal setae; inner flagellum multi-articulated, with 1 small seta in each segment; outer flagellum multi-articulated, with various aesthetascs on basial segments.

Antenna (Fig. 4C) Biramous, protopod unsegmented with 3 apical setae; exopod with 1 strong outer spine and 41 marginal setae.

Mandible (Fig. 4D) Without palp.

Maxillule Segmented palp with 4 apical setae, and 2 reduced setae and 1 reduced spine on basial segment; coxal endite with 34 setae; basal endite with 4 setae above coxal margin and 4 marginal setae and 10 marginal spines; outer lobe reduced, without setae.

Maxilla (Fig. 4E) Coxal endite with 33 setae; distal endite with 4 setae; basial endites with 8 setae each; palp with 4 apical setae; scaphognathite with 66-68 marginal setae.

Maxilliped 1 Coxa with 16 marginal setae; basis with 35 marginal setae; exopod with 4 apical and $2+2$ subterminal setae; endopod of 4 segments, ischium, merus, and carpus with $7 / 2,4 / 1$, and $3 / 0$ inner/outer setae, respectively, dactylus with 3 terminal and 1 subterminal setae.

Maxilliped 2 Coxa with 3 large setae; basis with 14 setae of variable length; exopod with 4 apical setae and 3 subterminal pairs of setae; ischium with 4 inner setae, 1 medial and 1 distal seta; carpus without setae; propodus with 3 inner setae; dactylus with 7 apical setae, of which 6 large and 1 short, and 1 short subterminal seta.

Maxilliped 3 Coxa and basis with 4 inner setae each; exopod with 4 apical setae and 6 pairs of subterminal setae; ischium and carpus with 4 and 2 and 1 inner setae, respectively; propodus with 3 inner setae, 1 medial and 2 outer ones; dactylus with 3 apical and 1 subterminal setae.

Pereiopods $1+2$ (Fig. $4 F$ ) Both pereiopods very similar; basis with 2, 2, and 3 setae; endopod 5-segmented with $3,2,0,2,3$ setae; exopod with 18 pairs and 2 terminal setae.

Pereiopod 3 (Fig. 4G) Basis with 3 setae; endopod 5-segmented with 2, 3, 1, 2, 4 setae; exopod with 15 pairs and 2 terminal setae.
Pereiopod 4 (Fig. 4H) Basis with 2 setae; endopod 5-segmented with 2, 4, 1, 2, 3 setae; exopod with 13 pairs and 2 terminal setae.

Pereiopod 5 (Fig. 4I) Basis with 2 setae; endopod 5-segmented with 1, 1, 1, 2, 3 setae; exopod reduced.

Pleon (Fig. 4A) Somites 1-3 partly fused, somite 4 free; ventro-lateral margins of somites $1-5$ with long thin setae.

Pleopods (Fig. 4A) Pleopods present as rudimentary buds on somites.

Uropods (Fig. 4J) Exopod with 1 outer and approximately 53 marginal setae; endopod with 47 marginal setae.

Telson (Fig. 4J) Outer pair of posterior processes longer than the other 4 inner pairs, of which the innermost is longer; 10 pairs of lateral marginal spines.

Nematocarcinus lanceopes Bate, 1888

Zoea I (Fig. 5A-K)

$\mathrm{CL}=2.0 \mathrm{~mm} \mathrm{SD} \pm 0.05 ; \mathrm{TL}=7.5 \mathrm{~mm} \mathrm{SD} \pm 0.05 ; N=15$

Carapace (Fig. 5A, B) Eyes sessile; with rostral spine, without denticles; pterygostomic spines present; posterior margin of carapace rounded; 1 dorsal anterior protuberance.

Antennule (Fig. 5C) Peduncle unsegmented, with 1 inner and 1 distal plumose seta; outer flagellum unsegmented, bearing 4 aesthetascs and 1 seta.

Antenna (Fig. 5D) Biramous, protopod unsegmented with 1 well-developed spine at inner distal part; exopod 6-segmented, with $1 / 1,0 / 1,1 / 10 / 1,1 / 1,4$ plumodenticulate setae; 1 strong ventral spine at basis.

Mandible (Fig. 5E) Incisor process with a few strong teeth; molar process with abundant small teeth; without palp.

Maxillule (Fig. 5F) Coxal endite with 7 setae; basial endite with 5 strong plumodenticulate cuspidate setae; palp 2-segmented with 3 apical setae on distal and 2 on proximal segment; outer lobe represented by 1 small protuberance and 3 plumose setae.

Maxilla (Fig. 5G) Proximal coxal endite with 11 setae; distal endite with 4 setae; basial endites with 4 setae each; palp incompletely 4-segmented, with $3,2,1,1,2$ setae; scaphognathite with 1 small inner seta, 4 marginal plumose setae and 1 terminal flagellum. 


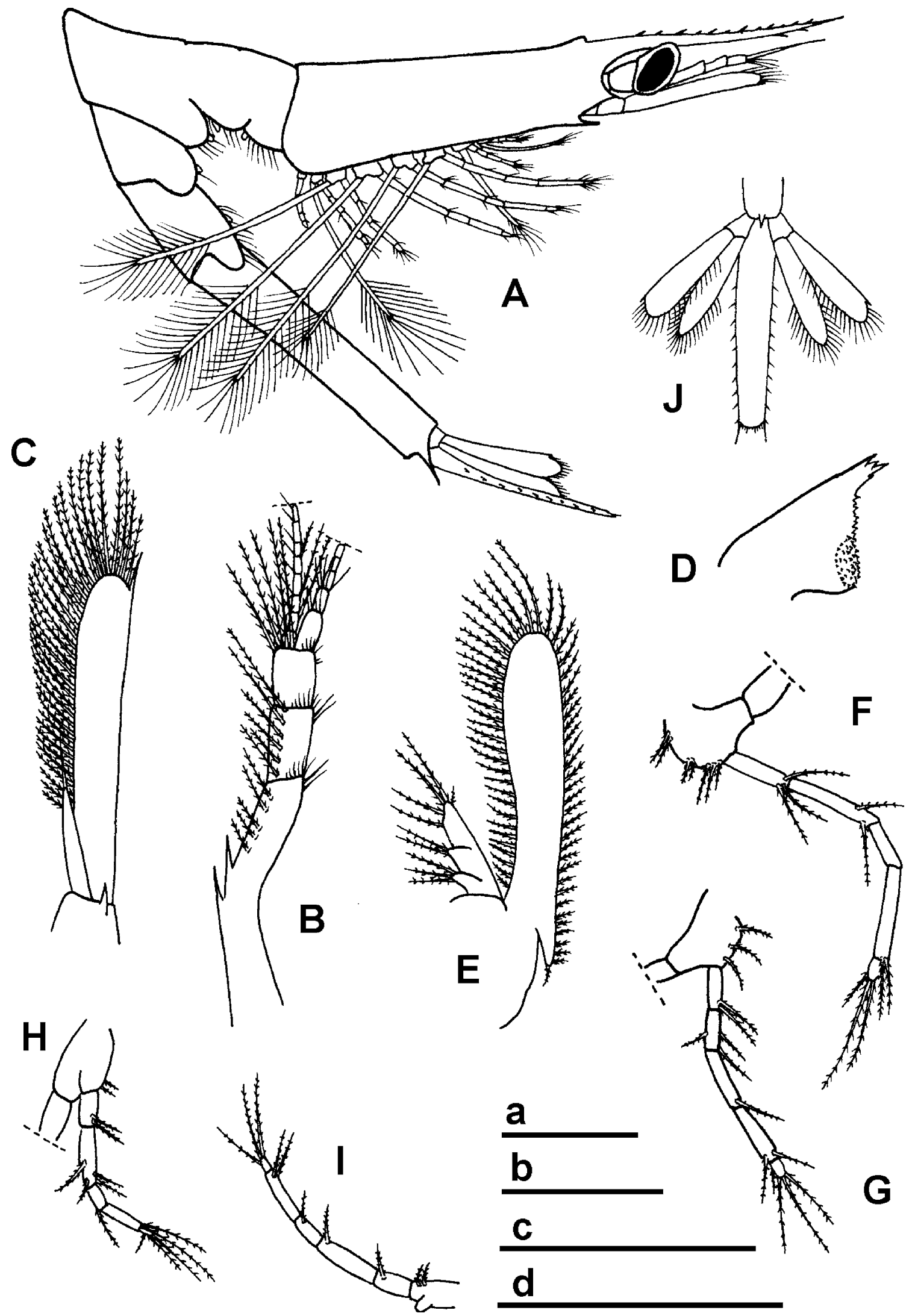

Fig. 4 Nematocarcinus longirostris Bate, 1888. Advanced zoeal stage; A general aspect, lateral view, B antennule, C antenna, D mandible, $\mathbf{E}$ scaphognathite and palp of maxilla, F pereiopod 1 and 2, G pereiopod 3, H pereiopod 4, I pereiopod 5. Scale bars $\mathbf{a}=2 \mathrm{~mm}(\mathbf{A}, \mathbf{J})$, $\mathbf{b}=1 \mathrm{~mm}(\mathbf{B}, \mathbf{C}), \mathbf{c}=1 \mathrm{~mm}(\mathbf{E}-\mathbf{I}), \mathbf{d}=0.5 \mathrm{~mm}(\mathbf{D})$. 


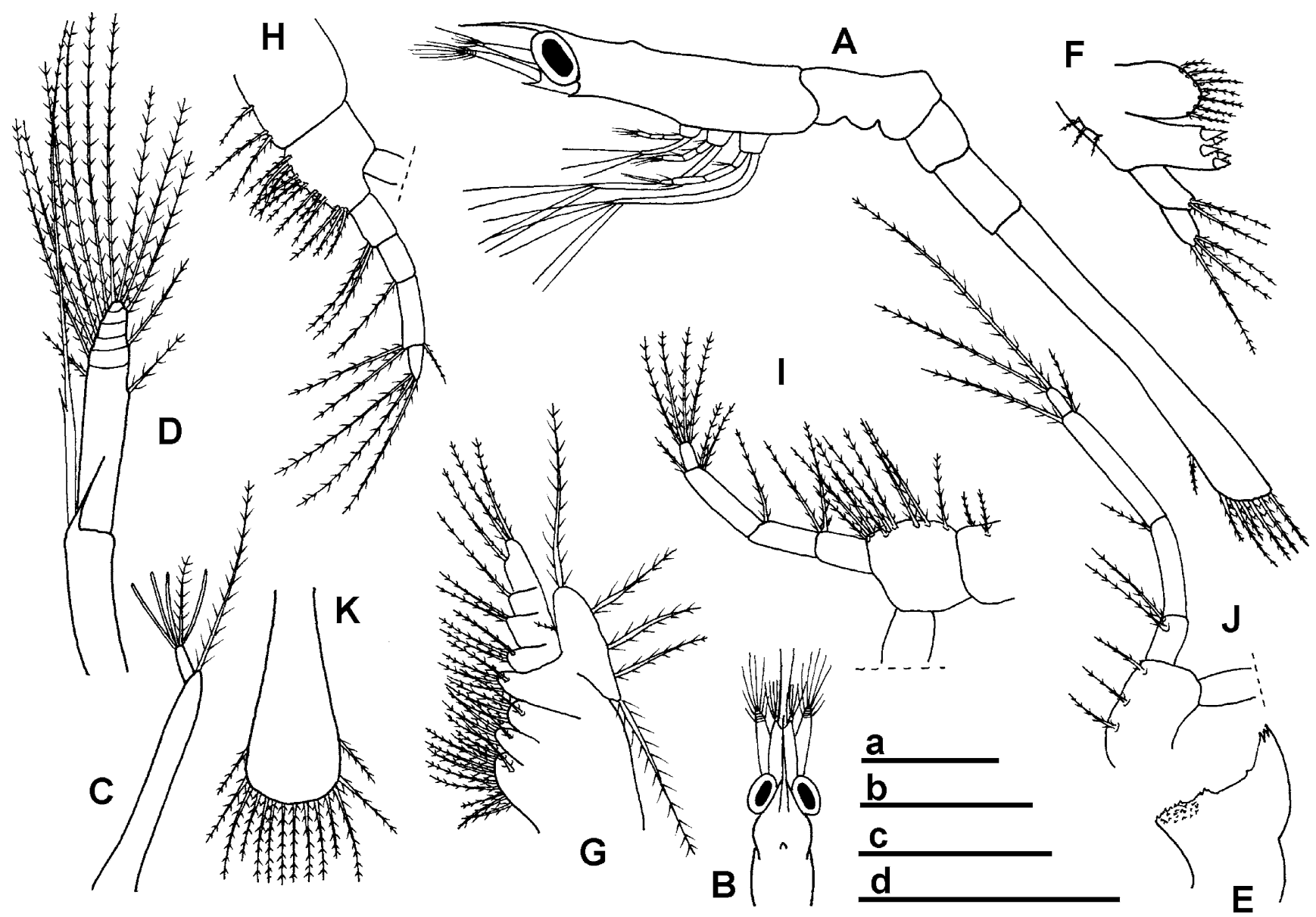

Fig. 5 Nematocarcinus lanceopes Bate, 1888. Zoea I; A general aspect, lateral view, B cephalothorax, dorsal view, C antennule, D antenna, $\mathbf{E}$ mandible, $\mathbf{F}$ maxillule, $\mathbf{G}$ maxilla, $\mathbf{H}$ maxilliped 1, I maxilliped 2, J maxilliped 3, $\mathbf{K}$ telson, dorsal view. Scale bars $\mathbf{a}=1 \mathrm{~mm}(\mathbf{A}, \mathbf{B}, \mathbf{K}), \mathbf{b}=0.2 \mathrm{~mm}(\mathbf{E}, \mathbf{F}, \mathbf{G}), \mathbf{c}=0.5 \mathrm{~mm}(\mathbf{C}, \mathbf{D})$, $\mathbf{d}=0.5 \mathrm{~mm}(\mathbf{H}-\mathbf{J})$.

Maxilliped 1 (Fig. 5H) Coxa with 3 setae; basis with 4 groups of 3 setae each; exopod with 3 apical setae; endopod of 4 segments with 2, 1, 2, and 4 (3 apical and 1 subterminal) setae.

Maxilliped 2 (Fig. 5I) Coxa with 2 setae; basis with 4 groups of $1,2,3$, and 3 setae, from proximal to distal segment; exopod with 4 apical setae; endopod of 4 segments with $2,1,2$, and 4 (3 apical 1 subapical) setae.

Maxilliped 3 (Fig. 5J) Basis with 3 setae; exopod with 5 apical setae; endopod of 4 segments with 2, 1, 2, and 2 apical setae.

\section{Pereiopods (Fig. 5A) Absent.}

Pleon (Fig. 5A) Somites 1-3 partly fused; somite 3 with 1 conspicuous dorsal prominence; somites 4-5 with latero-ventral margins rounded; margins of all somites smooth; somite 6 fused with telson; pleopods absent.
Telson (Fig. 5K) Convex, spatulous, without medial indentation; posterior margin with $7+7$ plumose setae. Inner 5 pairs (except pair 4) ending at same length to form straight postero-lateral setal margin.

Nematocarcinus lanceopes Bate, 1888

Zoea II (Fig. 6A-F)

$\mathrm{CL}=2.5 \mathrm{~mm} \mathrm{SD} \pm 0.05 ; \mathrm{TL}=9.3 \mathrm{~mm} \mathrm{SD} \pm 0.05 ; N=7$

Carapace (Fig. 6A, B) Eyes pedunculated; carapace similar to previous stage; with 2 dorsal protuberances.

Antennule (Fig. 6C) Peduncle 3-segmented; first segment with 6 setae above distal outer margin and 1 large seta above outer margin; segments 2 and 3 with 5 and 2 setae above distal outer margin; outer flagellum unsegmented, with 4 apical aesthetascs; inner flagellum represented by 1 large plumose seta, broadened at base.

Antenna (Fig. 6D) Biramous, protopod unsegmented with 1 well-developed spine at inner distal part; exopod 5 -segmented, with $1 / 2,1 / 1,0 / 10 / 1,5$ plumodenticulate setae; 1 strong ventral spine at basis.

Mandible Without changes.

Maxillule Coxal endite with 8 setae; basial endite with 3 strong and 4 thinner plumose spines. 


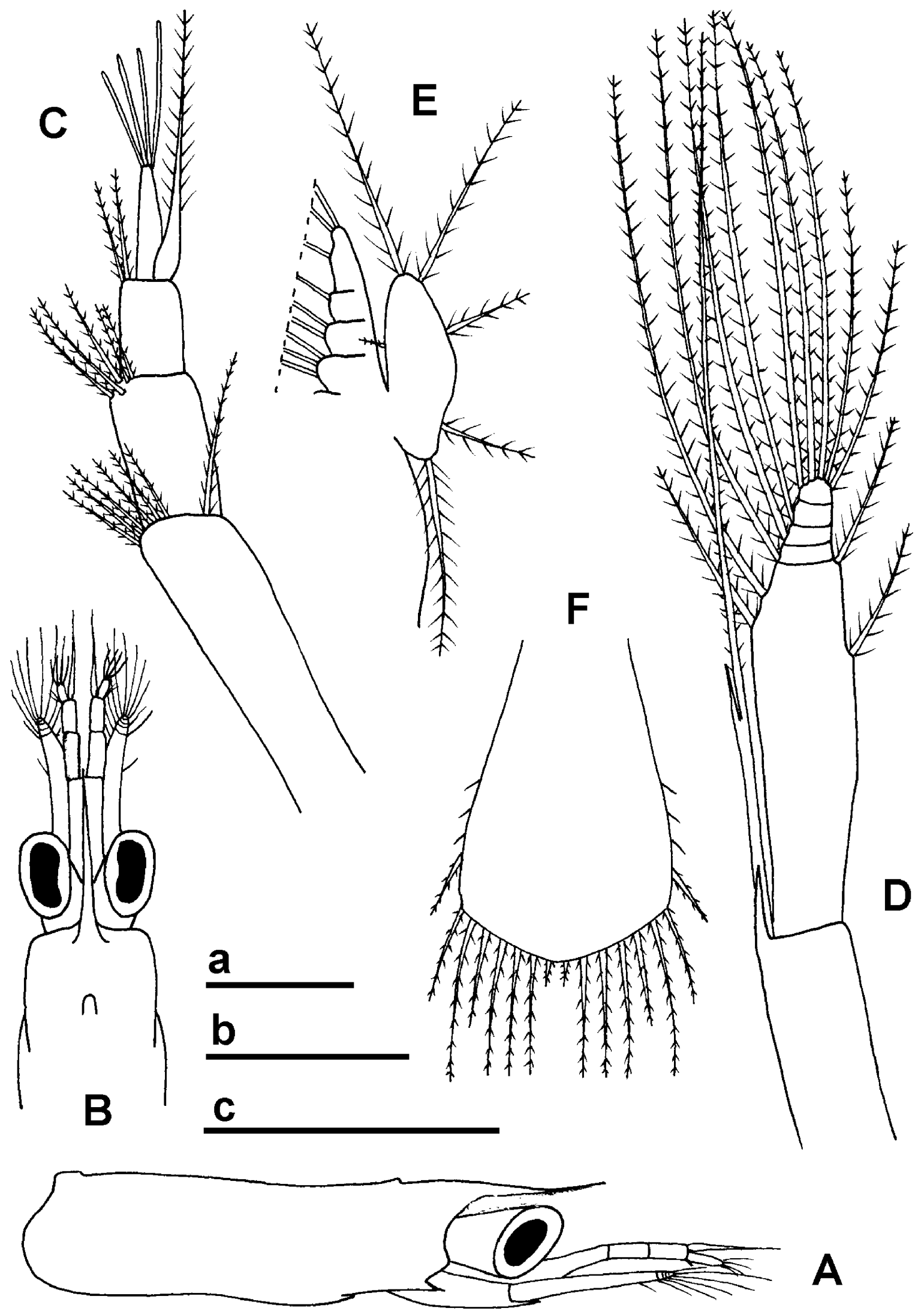


Fig. 6 Nematocarcinus lanceopes Bate, 1888. Zoea II; A cephalothorax, lateral view, B cephalothorax, dorsal view, C antennule, D antenna, E maxilla, $\mathbf{F}$ telson, dorsal view. Scale bars $\mathbf{a}=0.2 \mathrm{~mm}(\mathbf{E})$, $\mathbf{b}=1 \mathrm{~mm}(\mathbf{A}, \mathbf{B}, \mathbf{F}), \mathbf{c}=0.5 \mathrm{~mm}(\mathbf{C}, \mathbf{D})$.

Maxilla (Fig. 6E) Coxal endite proximally with 13-14 setae.

Maxilliped 1 Basis with 4 groups of 3, 3, 5, and 3 setae from proximal to distal part; endopod with $3,1,2$, and 4 setae.

Maxilliped 2 Exopod with 2 apical setae and 4 pairs of subterminal setae; endopod with incomplete segmentation between carpus and propodus, ischium with 4 internal setae.

Maxilliped 3 Exopod with 2 apical setae and 6 pairs of subterminal setae; endopod of 5 segments, carpus with 1 outer and without inner seta; the other segments without changes to previous stage.

Pereiopods First pair of pereiopods represented by small buds.

Pleon Without changes.

Telson (Fig. 6F) Convex, with $8+8$ processes, central pair of minor size; pairs 2-4 and 6 ending at same length to form straight postero-lateral setal margin; with $3+3$ short lateral spines.

\section{Discussion}

Sampling and rearing method

One of the great advantages of deep-sea studies in polar seas is the comparatively low variability of temperature throughout the water column when compared to other seas. This facilitates the sampling of live deep-sea organisms without causing too much physiological damage to the animals from great temperature shocks while the sampling gear comes up to the sea surface and, in addition, without great technical needs. Most crucial for the survival of shrimp specimens in the present case was the amount of benthos material and the size of stones and gravel trawled and mixed with the live biological material when using an AGT. In the case of the fragile Nematocarcinidae, this often caused loss of antennae and legs. Especially the loss of legs affected the survival of ovigerous females negatively. Embedded in mud, shrimps generally survived the sampling much better and physical damage to the specimens appeared to be reduced. Whereas non-ovigerous females of $N$. lanceopes in many cases recuperated quickly from the sampling stress once they were kept in the aquarium, ovigerous females hardly recovered. This might be cer- tainly due to great changes in pressure during sampling causing irreversible damage. However, in addition, our impression was that the egg batch impeded enhanced ventilation by pleopodal movements, which may increase the provision of oxygen-rich water towards the gill chambers. Such ventilation activity was the only obvious behaviour in non-ovigerous specimens for many hours until complete recovery from the sampling stress.

Due to the problem of keeping live ovigerous females of $N$. lanceopes, the incubation of an advanced egg batch was the only possibility to obtain larvae, which, in addition, allowed for direct species identification. Larvae hatched during the first night of incubation (see also Materials and methods) showed no variability in morphology and were actively moving; thus they are assumed to resemble larvae hatched in nature. Hatches from subsequent nights showed a high degree of mortality and consequently have been discarded. Presumably, lacking parental care, such as cleaning of the egg batch and/or oxygen provision through pleopodal movements/ventilation by the female, did not allow for optimal developmental conditions.

\section{Larval identification}

The Nematocarcinidae are a true deep-sea family. Its taxonomic status, identification and species distribution suffered from great confusion in past work, including synonymous use of species names (e.g. Zarenkov 1968; Retamal 1981; Kirkwood 1984; Boschi et al. 1992). Adult specimens in many cases are difficult to distinguish, which holds especially true for $N$. lanceopes and $N$. longirostris. Both species are distinguished mainly by the number of dorsal rostral spines and the presence/ absence of pterygostomian spines (after Kirkwood 1984; Tiefenbacher 1990; see also Boschi et al. 1992). Whereas more recent work has shown that $N$. lanceopes is endemic to the high Antarctic Weddell Sea and great parts of the Scotia Sea (Arntz and Gorny 1991; Gutt et al. 1991; Gorny 1999; Romero et al. 2003), the wide circum-Antarctic and eastern-Antarctic distribution of $N$. longirostris (compare with Introduction; Kirkwood 1984; Gorny 1999) in some cases is doubtful. This has been supported by Burukovsky (2000), who supposed $N$. longirostris to be a complex of three species. Recent investigations, however, so far confirm that the species found in the south-western Atlantic is N. longirostris (e.g., Boschi et al. 1992; Gorny 1999; Burukovsky 2000).

Since the first two zoeal stages obtained from plankton hauls in this area did not show morphological variability and can thus be undoubtedly assigned to one single species, its relation to $N$. longirostris is very likely. The advanced larva obtained from these catches does already resemble particular rostral characteristics of the adult stage (cf. Kirkwood 1984; Boschi et al. 1992), albeit a clear relation to the early zoeal stages is not possible due to the lack of intermediate stages. 
The early larval stages of both species described in this work are very difficult to distinguish. This resembles, on the one hand, the taxonomic problem within the adult Nematocarcinidae. On the other hand, it is also typical of early ontogenetic stages within the Caridea in general (e.g. Albornoz and Wehrtmann 1997). The first two zoeal stages of both species can only be clearly distinguished by the length and position of the setae on the postero-lateral margin of the telson (compare Fig. 2K with Fig. 5K, and Fig. 3F with Fig. 6F). In addition, the basis, the third and fourth segments of the endopod of the third maxilliped of the zoea I instar (Figs. 2J, 5J), as well as the coxal setation of the first maxilliped (Figs. $2 \mathrm{H}, 5 \mathrm{H}$ ), and the first segment of the endopod of the second maxilliped (Figs. 2I, 5I) show differences in setation in both species, which may aid larval identification. Morphological and intraspecific variability should increase in the subsequent ontogenetic stages, which remains an important subject for future study. Morphological similarity in the early zoeal stages again underlines the need for molecular markers in order to facilitate identification.

The early larvae of both $N$. lanceopes and $N$. longirostris are of primitive morphology with no indication of pereiopods and pleopodal buds. Even the advanced stage of $N$. longirostris (Fig. 4A) from our point of view still needs at least two further moults to reach a benthic decapodid stage, since the pereiopodal exopods do not yet show an indication of reduction (only in the pereiopod 5, Fig. 4I). The same holds true for the pleopods, which lack development and are still present as rudimentary buds only (Fig. 4A).

\section{Caridean reproduction in the (polar) deep sea}

Larval morphology in both nematocarcinid species clearly indicates an extended larval developmental mode though various zoeal stages; the detailed description of the complete developmental mode remains for further study in laboratory rearing. This is an outstanding feature for shrimp living in deep-sea and/or high-latitudinal environments, since caridean reproductive modes and larval developments have been frequently shown to follow a latitudinal and thus temperature-dependent shift, resulting, e.g., in a latitudinal cline in egg size (Gorny et al. 1992) and larval size at hatching, a reduction in the number of eggs/larvae per female and morphologically advanced larvae at hatching (Thatje 2004). Traits to abbreviate larval developments, principally a higher energetic investment into the individual larva by the female (Thatje et al. 2004a; b), from an evolutionary point of view should have been forced by the mismatch of prolonged developmental times (lowered metabolism) and short periods of primary production at (sub-) polar temperatures (Clarke 1982, 1993a; Thatje et al. 2003). These characteristics coincide very well with the largest aquatic environment on earth, the deep sea, except for the factor pressure, which is unique to this environment (Thiel et al. 1996). Although various autecological studies on shrimp reproduction at high latitudes have shown that shrimp in general follow a latitudinal pattern in reproduction (Thatje 2004, and references therein), the reproductive strategy in the Southern Ocean Nematocarcinidae remains surprising. In several aspects, such as low fecundity and big sized eggs (Gorny et al. 1992; Gorny and George 1997), the Nematocarcinidae follow some commonly known adaptations to low temperatures and short periods of food availability in the Caridea. However, the extended mode in larval development is a new observation for Antarctic shrimp, and actively feeding larvae already in the first zoeal stage require an exportation of larvae from the deep sea into the euphotic zone. In southern spring, in the widely ice-covered Weddell Sea, primary production begins in the coastal polynia. These open waters are locally restricted and show great variability in extension, which mainly depends on the intensity of katabatic winds. One suggestion might be that nematocarcinid larvae in the high Antarctic Weddell Sea use deep-water upwelling phenomena in the polynia as a passive transport mechanism into the euphotic zone. In the laboratory larvae showed rather low motility and larvae do not contain large amounts of lipids, which would facilitate their upward drift to shallower depths.

Another potential life history adaptation, however, of adults to support the planktotrophic life of their larvae might be their occasional occurrence in the pelagic. Although at least $N$. lanceopes has been observed quite often on the seafloor in situ (Gutt et al. 1991), and its feeding mode and morphology of the mouthparts should not allow for planktonic feeding (Kirkwood 1984; Storch et al. 2001), nematocarcinid species, such as $N$. longirostris, have been obtained occasionally from pelagic trawls. For this reason they have been frequently described as either bathypelagic or bathybenthic (Yaldwyn 1965; Kirkwood 1984; Iwasaki and Nemoto 1987). The intriguing question is whether the occasional pelagic occurrence of adult Nematocarcinidae is a familyspecific behaviour related to larval release into the water column. Interestingly, we caught pelagic first zoeae of $N$. lanceopes right at the beginning of the spring bloom in the polynia, indirectly indicating a direct response in larval release to improved food availability.

It is not yet clear whether nematocarcinid larvae show a partially endotrophic mode combined with facultative feeding in the first zoea. Although large lipid reserves were not visible microscopically, a certain degree of endotrophy may still be possible in the first zoeal stage, and would also allow for enduring periods of starvation. Such adaptation might be crucial to survive variable food availability in early spring (e.g., opening and closing of the polynia). A high resistance to starvation, however, may be assumed and is known to be a common feature in caridean larvae in general (Wehrtmann 1991; Thatje et al. 2004a, b). 
Acknowledgements Anna Pasternak and Jan Michels kindly sorted the plankton material from the Weddell Sea onboard RV "Polarstern". This work would not have been possible without the support by the captains and crews of the RV "Walther Herwig", "Shinkai Maru" and "Polarstern". Thanks are due to José A. Cuesta and two anonymous reviewers for their detailed comments on the manuscript.

\section{References}

Albornoz L, Wehrtmann IS (1997) Descripción y clave de los primeros estadíos larvales de camarones carídeos (Decapoda: Hippolytidae, Alpheidae, Rhynchocinetidae) de aguas costeras de Chile. Invest Mar Valparaíso 25:121-133

Anger K (2001) The biology of decapod crustacean larvae. Crustacean issues 14. Balkema, Lisse

Anger K, Thatje S, Lovrich GA, Calcagno JA (2003) Larval and early juvenile development of Paralomis granulosa reared at different temperatures: tolerance of cold and food limitation in a lithodid crab from high latitudes. Mar Ecol Prog Ser 253:243251

Anger K, Lovrich GA, Thatje S, Calcagno JA (2004) Larval and early juvenile development of Lithodes santolla (Molina, 1782) (Decapoda: Anomura: Lithodidae) reared at different temperatures in the laboratory. J Exp Mar Biol Ecol 306:217-230

Arntz WE, Gorny M (1991) Shrimp (Decapoda, Natantia) occurrence and distribution in the eastern Weddell Sea, Antarctica. Polar Biol 11:169-177

Arntz WE, Brey T, Gerdes D, Gorny M, Gutt J, Hain S, Klages M (1992) Patterns of life history and population dynamics of benthic invertebrates under the high Antarctic conditions of the Weddell Sea. In: Colombo G, Ferrari I, Ceccherelli VU, Rossi $\mathrm{R}$ (eds) Marine eutrophication and population dynamics: proceedings of 25th European marine biology symposium. Olsen \& Olsen, Fredensborg, pp 221-230

Arntz WE, Gorny M, Soto R, Lardies MA, Retamal M, Wehrtmann IS (1999) Species composition and distribution of decapod crustaceans in the waters off Patagonia and Tierra del Fuego, South America. Sci Mar 63 [Suppl 1]:303-314

Boschi EE, Fischbach CE, Iorio MI (1992) Catálogo ilustrado de los crustáceos estamatópodos y decápodos marinos de Argentina. Frente Marit (Montevideo) 10:7-94

Burukovsky RN (2000) Taxonomy of shrimps from the genus Nematocarcinus (Crustacea, Decapoda, Nematocarcinidae). 2. Revision of $N$. longirostris and $N$. altus, correction of species diagnosis in $N$. sigmoides and $N$. lanceopes, and description of new species, $N$. batei and $N$. romenskyi (in Russian). Zool Zh 79(3):282-290

Burukovsky RN (2001) Taxonomy of Nematocarcinus (Decapoda, Nematocarcinidae). Description of Nematocarcinus from waters of the American continent. Zool Zh 80(12):1429-1443

Calcagno JA, Thatje S, Anger K, Lovrich GA, Kaffenberger A (2003) Changes in biomass and chemical composition during lecithotrophic larval development of the southern stone crab, Paralomis granulosa (Jacquinot). Mar Ecol Prog Ser 257:189196

Cartes JE (1993) Diets of two deep-sea decapods: Nematocarcinus exilis (Caridea: Nematocarcinidae) and Munida tenuimana (Anomura: Galatheidae) on the western Mediterranean slope. Ophelia 37:213-229

Ciechomski JD, Ehrlich MD, Lasta CA, Sanchez RP (1979) Campañas realizadas por el buque de investigación 'Walther Herwig' en el Mar Argentino, desde mayo hasta noviembre 1978. Organización y reseña de datos básicos obtenidos. Contrib Inst Nac Invest Des Pesq (Mar del Plata) 374:1-311

Clarke A (1982) Temperature and embryonic development in polar marine invertebrates. Int J Invertebr Reprod 5:71-82

Clarke A (1987) Temperature, latitude and reproductive effort. Mar Ecol Prog Ser 38:89-99
Clarke A (1993a) Reproductive trade-offs in caridean shrimps. Funct Ecol 7:411-419

Clarke A (1993b) Egg size and egg composition in polar shrimps (Caridea; Decapoda). J Exp Mar Biol Ecol 168:189-203

Cousseau MB, Hansen JE, Gru D (1979) Campañas realizadas por el buque de investigación 'Shinkai Maru' en el Mar Argentino, desde abril de 1978 hasta abril de 1979. Organización y reseña de datos obtenidos. Contrib Inst Nac Invest Des Pesq (Mar del Plata) 373:1-625

Gorny M (1999) On the biogeography and ecology of the Southern Ocean decapod fauna. Sci Mar 63 [Suppl 1]:367-382

Gorny M, George MR (1997) Oocyte development and gonad production of Nematocarcinus lanceopes (Decapoda: Caridea) in the eastern Weddell Sea, Antarctica. Polar Biol 17:191198

Gorny M, Arntz WE, Clarke A, Gore DJ (1992) Reproductive biology of caridean decapods from the Weddell Sea. Polar Biol 12:111-120

Gurney R (1942) Larvae of decapod Crustacea. R Soc (Lond):1306

Gutt J, Gorny M, Arntz WE (1991) Spatial distribution of Antarctic shrimps (Crustacea: Decapoda) by underwater photography. Polar Biol 3:363-369

Haynes EB (1981) Early zoeal stages of Lebbeus polaris, Eualus suckleyi, E. fabricii, Spirontocaris arcuata, S. achotensis and Heptacarpus camtschatiens (Crustacea, Decapoda, Caridea, Hippolytidae) and morphological characterization of zoea Spirontocaris and related genera. US Fish Bull 79(3):421-440

Haynes EB (1985) Morphological development, identification, and biology of larvae of Pandalidae, Hippolytidae, and Crangonidae (Crustacea, Decapoda) of the northern north Pacific Ocean. US Fish Bull 83:501-521

Iwasaki N, Nemoto T (1987) Distribution and community structure of pelagic shrimps in the Southern Ocean between $150^{\circ} \mathrm{E}$ and $115^{\circ} \mathrm{E}$. Polar Biol 8:121-128

Kirkwood JM (1984) A guide to the Decapoda of the Southern Ocean. ANARE Res Notes 11: 47

Retamal MA (1981) Catálogo ilustrado de los crustáceos decápodos de Chile. Gayana Zool 44:1-110

Romero MC, Tapella F, Lovrich GA, Thatje S (2003) Reproductive modes and distribution of benthic decapod crustaceans along the Scotia Arc. In: Arntz WE, Brey T (eds) The expedition Antarktis XIX/5 (LAMPOS) of RV “Polarstern" in 2002. Ber Polarforsch Meeresforsch (Rep Polar Mar Res) 462:67-72

Spivak ED (1997) Los crustáceos decápodos del Atlántico sudoccidental $\left(25^{\circ}-55^{\circ} \mathrm{S}\right)$ : distribución y ciclos de vida. Invest Mar Valparaíso 25:73-92

Storch V, Bluhm BB, Arntz WE (2001) Microscopic anatomy and ultrastructure of the digestive system of three Antarctic shrimps (Crustacea: Decapoda: Caridea). Polar Biol 24:604-614

Thatje S (2004) Reproductive trade-offs in benthic decapod crustaceans of high southern latitudes: tolerance of cold and food limitation. Berichte Polarforsch Meeresforsch (Rep Polar Mar Res) 483:1-183

Thatje S, Schnack-Schiel S, Arntz WE (2003) Developmental tradeoffs in Subantarctic meroplankton communities and the enigma of low decapod diversity in high southern latitudes. Mar Ecol Prog Ser 260:195-207

Thatje S, Lovrich GA, Torres G, Hagen W, Anger K (2004a) Changes in biomass, lipid, fatty acid and elemental composition during abbreviated larval development of the Subantarctic shrimp Campylonotus vagans. J Exp Mar Biol Ecol 301:159-174

Thatje S, Lovrich GA, Anger K (2004b) Egg production, hatching rates, and abbreviated larval development of Campylonotus vagans Bate, 1888 (Crustacea: Decapoda: Caridea) in Subantarctic waters. J Exp Mar Biol Ecol 301:15-27

Thiel H, Pörtner HO, Arntz WE (1996) Marine life at low temperatures - a comparison of polar and deep-sea characteristics. In: Uiblein F, Ott J, Stachowitsch M (eds) Deep-sea and extreme shallow-water habitats: affinities and adaptations. Biosyst Ecol Ser 11:183-219 
Tiefenbacher L (1990) Beiträge zur Taxonomie von Nematocarcinus longirostris Bate, 1888 und Nematocarcinus lanceopes Bate, 1888, neu für die westliche Antarktis (Crustacea, Decapoda, Natantia). Spixiana 13(3):229-235

Wehrtmann IS (1991) How important are starvation periods in early larval development for survival of Crangon septemspinosa larvae? Mar Ecol Prog Ser 73:183-190

Wenner EL (1979) Distribution and reproduction of nematocarcinid shrimp (Decapoda, Caridea) from the northwestern North Atlantic. Bull Mar Sci 29:380-393

Williamson DI (1962) Crustacea Decapoda: larvae. III. Caridea, Families Oplophoridae, Nematocarcinidae and Pasiphaeidae. Fiches Identif Zooplancton 92:5
Williamson DI (1982) Larval morphology and diversity. Biol Crustacea 2:43-110

Yaldwyn JC (1965) Antarctic and subantarctic decapod Crustacea. In: Mieghem J van, Oye P van (eds) Biogeography and ecology in the Antarctic. Junk, The Hague, pp 324-332

Zarenkov NA (1968) Crustacea Decapoda collected by the Soviet Antarctic Expeditions in the Antarctic and Antiboreal regions. Biol Rep Sov Antarct Exped (1955-58) 4:153-201 